\title{
Radioactivity concentrations and their radiological significance in sediments of the Tema Harbour (Greater Accra, Ghana)
}

\author{
Benjamin O. Botwe ${ }^{\mathrm{a}, \mathrm{b},{ }^{*}}$, Antonio Schirone ${ }^{\mathrm{c}}$, Ivana Delbono ${ }^{\mathrm{c}}$, Mattia Barsanti ${ }^{\mathrm{c}}$, \\ Roberta Delfanti ${ }^{c}$, Peter Kelderman ${ }^{a}$, Elvis Nyarko ${ }^{b}$, Piet N.L. Lens ${ }^{a}$ \\ ${ }^{a}$ UNESCO-IHE Institute for Water Education, PO Box 3015, 2601 DA Delft, The Netherlands \\ ${ }^{\mathrm{b}}$ Department of Marine and Fisheries Sciences, University of Ghana, PO Box LG 99, Legon, Accra, Ghana \\ c ENEA, Marine Environment Research Centre, PO Box 224, I-19100 La Spezia, Italy
}

\section{A R T I C L E I N F O}

\section{Article history:}

Received 7 July 2016

Accepted 6 December 2016

Available online $\mathrm{xxx}$

\section{Keywords:}

Dose rates

ERICA tool

Radioactivity

Tema Harbour

Sediments

\begin{abstract}
A B S T R A C T
Studies on environmental radioactivity in tropical Africa are scarce. Therefore, a baseline study of natural $\left({ }^{238} \mathrm{U},{ }^{210} \mathrm{~Pb},{ }^{226} \mathrm{Ra},{ }^{232} \mathrm{Th},{ }^{228} \mathrm{Ra},{ }^{228} \mathrm{Th},{ }^{40} \mathrm{~K}\right)$ and anthropogenic $\left({ }^{137} \mathrm{Cs}\right)$ radionuclides was carried out on Tema Harbour (Greater Accra, Ghana) surface sediments and on their radiological significance. Grab surface sediment samples were collected from 21 stations within the Tema Harbour and their radioactivity concentrations measured by gamma spectrometry. The mean sediment radioactivity concentrations (Bq kg ${ }^{-1} \mathrm{dw}$ ) were 34 for ${ }^{238} \mathrm{U}, 210$ for ${ }^{210} \mathrm{~Pb}, 14$ for ${ }^{226} \mathrm{Ra}, 30$ for ${ }^{232} \mathrm{Th}, 29$ for ${ }^{228} \mathrm{Ra}, 31$ for ${ }^{228} \mathrm{Th}, 320$ for ${ }^{40} \mathrm{~K}$, and 1.5 for ${ }^{137} \mathrm{Cs}$. Large ${ }^{238} \mathrm{U} /{ }^{226} \mathrm{Ra}$ disequilibria were observed in the harbour sediments and a complex dynamics of several mixed sources of sediments within the Tema Harbour can be inferred from the spatial variations in the radioactivity concentrations. The estimated total absorbed dose rate in air $(D)$, radium equivalent activity $\left(\mathrm{Ra}_{\mathrm{eq}}\right)$, external hazard index $\left(H_{e x}\right)$, annual gonadal dose equivalent (AGDE) and annual effective dose equivalent (AEDE) indicated no significant radiological risks from the sediment radioactivity concentrations. Application of the Environmental Risk from Ionising Contaminants Assessment and Management tool (ERICA) confirmed that the potential dose rates to biota from the sediment radioactivity concentrations are unlikely to pose appreciable ecological risks. The radioactivity levels are compared with levels reported in sediments from other coastal areas of the world. () 2016 The Egyptian Society of Radiation Sciences and Applications. Production and hosting by Elsevier B.V. This is an open access article under the CC BY-NC-ND license (http://creativecommons.org/licenses/
\end{abstract}

by-nc-nd/4.0/).

\section{Introduction}

Radionuclides constitute an important source of ionising radiation exposure to human and non-human populations (Kam \& Bozkurt, 2007; UNSCEAR, 2000), which can cause harmful biological effects such as DNA damage and cancer (Little, 2003; Ravanat et al., 2014; Schmid \& Schrader, 2007). Radionuclides such as ${ }^{238} \mathrm{U},{ }^{210} \mathrm{~Pb},{ }^{226} \mathrm{Ra},{ }^{232} \mathrm{Th},{ }^{228} \mathrm{Ra},{ }^{228} \mathrm{Th}$ and ${ }^{40} \mathrm{~K}$ are widely distributed in the environment as a result of their natural occurrence in the Earth's crust or the atmosphere. The human population worldwide receives an average annual radiation dose of $2.4 \mathrm{mSv}^{-1}{ }^{-1}$, about $80 \%$

\footnotetext{
* Corresponding author. UNESCO-IHE Institute for Water Education, PO Box 3015 , 2601 DA Delft, The Netherlands.

E-mail address: boseibotwe@yahoo.co.uk (B.O. Botwe).

Peer review under responsibility of The Egyptian Society of Radiation Sciences and Applications.
}

of which comes from naturally-occurring radionuclides, the remaining part is largely due to artificial sources of which fallout radionuclides account for only $0.4 \%$ (UNSCEAR, 2000). Fallout radionuclides such as ${ }^{90} \mathrm{Sr},{ }^{137} \mathrm{Cs}$ and ${ }^{239+240} \mathrm{Pu}$ are derived mainly from global nuclear tests conducted between the mid 1940s and the 1980s, as well as from nuclear accidents (Livingston \& Povinec, 2000). In addition to their potential ionising effects, radionuclides may be toxic and can undergo bioconcentration and bioaccumulation (Hassona, Sam, Osman, Sirelkhatim, \& LaRosa, 2008; Sirelkhatim, Sam, \& Hassona, 2008) and adversely impact human and ecosystem health. Assessment of radioactivity in the environment is useful for the protection of human health and the environment from the harmful effects of ionising radiation, and is therefore of great interest (Ulanovsky, Pröhl, \& Gómez-Ros, 2008). Most naturally-occurring and fallout radionuclides can be detected and measured at extremely low concentrations; this makes them excellent tracers for many environmental processes as well as 
unique dating tools. Thus, they have found a wide range of applications in environmental studies such as isotope hydrogeology (Divine \& McDonnell, 2005), water masses circulation (Broecker, 1982), sediment dating and sedimentation (Hernández, 2016; Mabit et al., 2014; Mahu et al., 2016).

Although the West African coastal environment lacks the presence of nuclear industries, it may be impacted by contaminated areas as a result of ocean and atmospheric dispersal and redistribution. Furthermore, anthropogenic activities in the West African coastal environment such as shipping, offshore oil and gas exploration and production, mining, industrialisation, urbanisation, and agricultural production can potentially add to measured levels of radionuclides in the environment (Al-Trabulsy, Khater, \& Habbani, 2011; El Mamoney \& Khater, 2004; Nyarko et al., 2011). In the coastal environment, harbours may be particularly susceptible to anthropogenic influences and their sediments can act as sinks for radionuclides (Sugandhi, Joshi, \& Ravi, 2014). Harbours have hence been areas of interest when investigating radionuclide contamination in the coastal environment (Akram et al., 2006; Kumar et al., 2013; Papaefthymiou, Papatheodorou, Moustakli, Christodoulou, \& Geraga, 2007; Sam, ElGanawi, Ahamed, \& ElKhangi, 1998; Sugandhi et al., 2014). Sediment contamination by radionuclides of the ${ }^{238} \mathrm{U}$ and ${ }^{232} \mathrm{Th}$ decay-series and ${ }^{40} \mathrm{~K}$ is of particular interest from radiological point of view, as they can form the basis of radiological assessments for the human population. The Environmental Risk from Ionising Contaminants Assessment and Management tool (ERICA) developed by the European Commission provides an integrated approach to the assessment and management of environmental risks from ionising radiation (Beresford et al., 2007) and can be applied to assess the potential ecological impact of radionuclide-contaminated environments.

Currently, there is not much information on radioactivity levels in the coastal marine environment of the West African region, including Ghana. In Ghana, the few radioactivity studies in the coastal environment have focussed on beach sediments (Amekudzie et al., 2011; Nyarko et al., 2011), estuarine sediments (Mahu et al., 2016) and produce water from offshore oil fields (Kpeglo et al., 2016). Due to rapid growth of urbanisation and industrialisation in Tema, increasing maritime traffic and infrastructural expansion works at the Tema Port is likely to intensify chemical contamination in the harbour. Monitoring of such developing coastal areas is, therefore, essential to ensure that these socio-econonic and develomental activities do not adversely affect human health and the proper functioning of coastal aquatic ecosystems. The objective of this study was to assess the radioactivity concentrations of natural ${ }^{238} \mathrm{U},{ }^{210} \mathrm{~Pb},{ }^{226} \mathrm{Ra},{ }^{232} \mathrm{Th},{ }^{228} \mathrm{Ra},{ }^{228} \mathrm{Th}$ and ${ }^{40} \mathrm{~K}$ ) and anthropogenic $\left({ }^{137} \mathrm{Cs}\right)$ radionuclides in surface sediments from the Tema Harbour in Ghana and their radiological and radioecological significance.

\section{Materials and methods}

\subsection{Description of the study area}

The Tema Harbour, situated in the Gulf of Guinea along the Ghana coast at Tema (Fig. 1), is semi-enclosed with a water area of $1.7 \mathrm{~km}^{2}$ within a wider harbour zone of $3.9 \mathrm{~km}^{2}$. It consists of the Main Harbour, the Fishing Harbour comprising the Inner Fishing Harbour, the Outer Fishing Harbour, and the Canoe Basin (Nyarko, Fletcher, Addo, Foli, \& Mahu, 2014). Water depths range from 7.5-11.4 $\mathrm{m}$ for the Main Harbour, 7.5-8.5 $\mathrm{m}$ for the Fishing Harbour and 3.5-7.0 $\mathrm{m}$ for the Canoe Basin (http://www.ghanaports.gov. gh). The Main Harbour has 14 berths, a total of $4580 \mathrm{~m}$ breakwater, a shipyard and dry dock for ship repairs, and a $240 \mathrm{~m}$ wide access channel. The harbour does not receive riverine inflows, but does receive wastewater from the Tema Township. The Fishing Harbour serves as a landing site for fishing vessels, where repairs and re-fuelling of marine crafts are also carried out. A 2010 feasibility study report by Halcrow Engineers (unpublished) on the Tema Harbour revealed that it is underlain mainly by gneiss rocks composed of feldspar, quartz and micaceous minerals. The Tema Harbour is located in an industrial environment and thus, it could be impacted by industrial activities.

\subsection{Sediment sampling}

Grab surface sediment samples were collected in November 2013 from 21 stations within the Tema Harbour (Fig. 1), excluding rocky areas and berths where ships had docked (e.g. the area between S7 and S14). Fourteen (14) of the sampling stations were located in the Main Harbour (S1-S14), three (3) stations in the Canoe Basin (S15-S17), and two (2) stations each in the Inner Fishing Harbour (S18 and S19) and the Outer Fishing Harbour (S20 and S21). Geographical coordinates of the sampling stations were recorded using a Garmin Global Positioning System (GPS). At each station, the redox potential $\left(E_{h}\right)$ was measured in situ near the sediment-water interface using a Hanna multi-parameter probe (HI 9829, Hanna Instruments, USA).

Sediment samples were collected using a $3.5 \mathrm{~L}$ Ekman bottom grab sampler. The sampling locations were approximately $200 \mathrm{~m}$ apart, covering a wide area and range of water depths to provide representative data on the radionuclide distribution in the harbour. To minimise potential loss of fine particles via leakage of water from the grab, it was ensured that only grabs that arrived firmly closed on the deck were sampled for analysis. In addition, only grabs that were not filled with sediment to the lid were used to assure minimal disturbance of the surface sediments.

About $100 \mathrm{~g}$ wet weight portions of surface sediments were taken with a clean plastic spoon into polyamide Rilsan ${ }^{\circledR}$ bags and securely closed. With extremely low potential for diffusion of materials across their surfaces (http://tub-ex.com/products/rilsan/), Rilsan ${ }^{\circledR}$ bags are suitable for collection and storage of sediment samples and they have been used in environmental monitoring programmes (Serigstad et al., 2010). To minimise contamination from the grab, sediments in direct contact with the grab were not used and the sampling spoon was washed with deionised water after each sampling. All sediment samples were kept on ice and transported to the Chemistry Laboratory at the Ghana Atomic Energy Commission (Greater Accra, Ghana) for further analyses.

\subsection{Sample analyses}

For the analyses of radionuclides, wet sediment samples were oven-dried at $50{ }^{\circ} \mathrm{C}$ till constant weight. Radiometric analyses of sediment samples were conducted at the ENEA S. Teresa laboratory (Italian National Agency for New Technologies, Energy and Sustainable Economic Development, La Spezia, Italy). The sediment samples were ground and placed in $5 \mathrm{~g}$ plastic vials of standard geometry, closed and sealed air-tight, and then stored for at least 22 days to ensure secular equilibrium between the parent nuclides and their short-lived daughter nuclides. The sealed samples were then counted for 2-3 days, and activities measured for ${ }^{210} \mathrm{~Pb}$ at $46.5 \mathrm{keV},{ }^{214} \mathrm{~Pb}$ at $352 \mathrm{keV},{ }^{212} \mathrm{~Pb}$ at $239 \mathrm{keV},{ }^{208} \mathrm{Tl}$ at $583 \mathrm{KeV},{ }^{228} \mathrm{Ac}$ at 338 and $911.0 \mathrm{keV},{ }^{234} \mathrm{Th}$ at 63.3 and $92.5 \mathrm{keV},{ }^{40} \mathrm{~K}$ at $1460 \mathrm{keV}$ and ${ }^{137} \mathrm{Cs}$ at $662 \mathrm{keV}$. The measured activities were decay-corrected with respect to the date of sediment sampling (Sirelkhatim et al., 2008) and associated errors were determined from l-sigma counting statistics (Nyarko et al., 2011). The activity of ${ }^{228}$ Th was obtained from the activity of its daughter ${ }^{212} \mathrm{~Pb}$ radionuclide and ${ }^{226} \mathrm{Ra}$ and ${ }^{228} \mathrm{Ra}$ from the activities of ${ }^{214} \mathrm{~Pb}$ and ${ }^{228} \mathrm{Ac}$, respectively. 


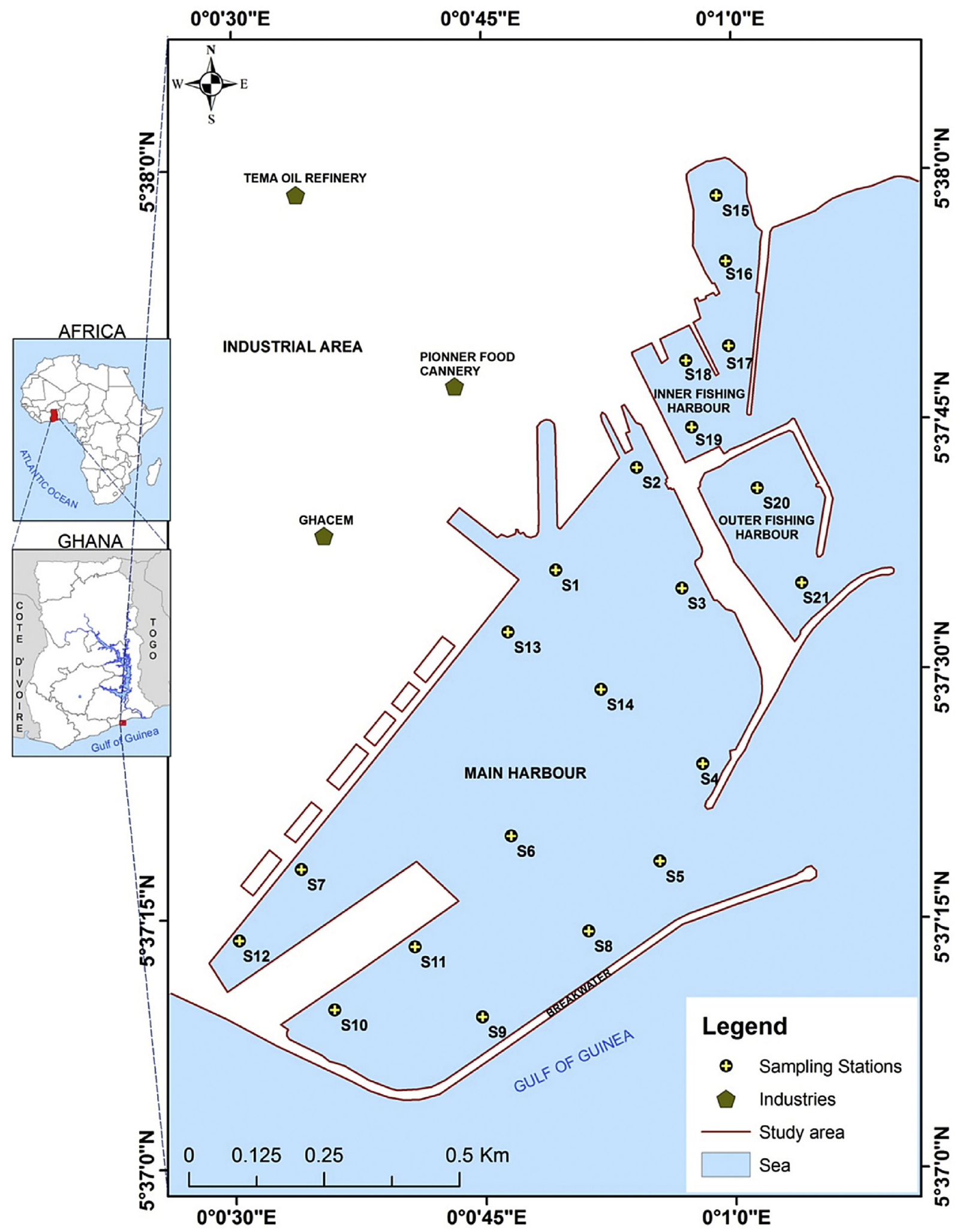

Fig. 1. Map of Tema Harbour (Greater Accra, Ghana) showing sediment sampling locations.

The average activity of ${ }^{228} \mathrm{Ac}$ and ${ }^{212} \mathrm{~Pb}$ was used as a proxy for ${ }^{232} \mathrm{Th}$ activity. Since no unsupported ${ }^{234} \mathrm{Th}\left({ }^{234} \mathrm{Th}_{\mathrm{ex}}\right)$ was observed, the supported ${ }^{234} \mathrm{Th}$ activity was used as a proxy for ${ }^{238} \mathrm{U}$ activity.

Samples were analysed using a Gamma spectrometer coupled to an ORTEC low background intrinsic germanium coaxial detector (17.6\% absolute efficiency, $1.8 \mathrm{keV}$ nominal resolution at $662 \mathrm{keV}$
${ }^{137}$ Cs gamma emission). Prior to the sample radioactivity analyses, the Gamma ray detectors were calibrated for measurement of ${ }^{40} \mathrm{~K}$ using the IAEA-385 Certified Reference Material (CRM), while calibrations for ${ }^{238} \mathrm{U}$ series radionuclides were performed using the CANMET (Canada Centre for Mineral and Energy Technology) Reference Standard (DL1a), being a U-Th ore in which ${ }^{210} \mathrm{~Pb}$ and 
${ }^{226} \mathrm{Ra}$ exist in secular equilibrium. Calibrations for ${ }^{232} \mathrm{Th}$ series radionuclides were also performed using the IAEA Reference Standard (RGTh-1) prepared by CANMET, while calibration for ${ }^{137} \mathrm{Cs}$ was performed using the Eckert \& Ziegler Analytics Reference Standard (QCYA48). Quality of all results was routinely checked by analysing IAEA-300 and IAEA-315 Reference Materials as well as detector blanks (empty sample containers) processed in a similar way as the actual samples. Correction of measured activities for selfadsorption effects was done based on measurements of the attenuation of a known ${ }^{210} \mathrm{~Pb}$ Gamma source by the samples.

\subsection{Radiological risk assessment}

Dredged radioactive-contaminated harbour sediments may be disposed of on land or used for other purposes such as building, which can potentially result in human exposure to ionising radiations and cause radiological effects. For human protection and appropriate handling of radioactive-contaminated sediments, it is essential to characterise the associated potential radiological risks. Five radiological hazard indices were estimated following established formulae to characterise the potential radiation dose to humans resulting from exposure to sediment radioactivity, viz. (1) total absorbed dose rate in air $(D),(2)$ radium equivalent activity $\left(\mathrm{Ra}_{\mathrm{eq}}\right),(3)$ external hazard index $\left(H_{e x}\right),(4)$ annual gonadal dose equivalent (AGDE), and (5) annual effective dose equivalent (AEDE).

The $D$ expresses the rate of exposure to gamma radiation in air at $1 \mathrm{~m}$ above the ground due to the activities of ${ }^{226} \mathrm{Ra},{ }^{232} \mathrm{Th}$ and ${ }^{40} \mathrm{~K}$ in the sediment samples. $\mathrm{Ra}_{\mathrm{eq}}$ is a weighted sum of the activity concentrations of ${ }^{226} \mathrm{Ra},{ }^{232} \mathrm{Th}$ and ${ }^{40} \mathrm{~K}$ in a sediment sample, which allows comparison with their individual ${ }^{226} \mathrm{Ra},{ }^{232} \mathrm{Th}$ and ${ }^{40} \mathrm{~K}$ activity concentrations (Sugandhi et al., 2014). $H_{e x}$ is a measure of the indoor radiation dose rate associated with external gamma radiation exposure from natural radionuclides in building materials and it is important when considering the suitability of sediments as building materials (Xinwei, Lingqing, \& Xiaodan, 2006). For human health safety, the value of $H_{e x}$ must not exceed 1.0 (Kurnaz et al., 2007; Xinwei et al., 2006). Owing to their relatively higher sensitivity to ionising radiation compared to other organs of the body, the gonads are considered to be at a high risk of radiation exposure and are therefore of great interest in radiological assessment (Kurnaz et al., 2007). The AGDE estimates the potential radiation dose that the gonads may receive from ${ }^{226} \mathrm{Ra},{ }^{232} \mathrm{Th}$ and ${ }^{40} \mathrm{~K}$. It is also usual to convert $D$ to AEDE to assess the dose rate to an individual from outdoor gamma radiation over a period of one year.

The $D$ and $\mathrm{Ra}_{\text {eq }}$ were calculated using Eqs. (1) and (2), respectively, following (El Mamoney \& Khater, 2004):

$D\left(\mathrm{nGy}_{\mathrm{h}} \mathrm{h}^{-1}\right)=0.462 \mathrm{~A}_{\mathrm{Ra}}+0.604 \mathrm{~A}_{\mathrm{Th}}+0.0417 \mathrm{~A}_{\mathrm{K}}$

$\mathrm{Ra}_{\mathrm{eq}}\left(\mathrm{Bq} \mathrm{kg}{ }^{-1}\right)=\mathrm{A}_{\mathrm{Ra}}+1.43 \mathrm{~A}_{\mathrm{Th}}+0.077 \mathrm{~A}_{\mathrm{K}}$

$H_{e x}$ was calculated using Eq. (3) following (Xinwei et al., 2006):

$H_{e x}=\left(A_{R a} / 370\right)+\left(A_{T h} / 259\right)+\left(A_{K} / 4810\right)$

AGDE and AEDE were calculated using Eqs. (4) and (5), respectively, following (Kurnaz et al., 2007).

$$
\begin{aligned}
& \operatorname{AGDE}\left(\mu S v . y^{-1}\right)=3.09 A_{R a}+4.18 A_{T h}+0.314 A_{K} \\
& \operatorname{AEDE}\left(\mu \mathrm{Sv}_{\mathrm{y}} \mathrm{y}^{-1}\right)=D\left(\mathrm{nGy} \cdot \mathrm{h}^{-1}\right) \mathrm{x} \\
& 8760 \mathrm{~h} \times 0.2 \times 0.7 \text { Sv.Gy.y }{ }^{-1} \times 10^{-3}
\end{aligned}
$$

\subsection{Radioecological risk assessment}

Radioactivity contamination in sediments may put aquatic organisms at risk of ionising radiation effects. Therefore, the ERICA tool (version 1.2) was applied to assess the potential dose rates to organisms in the harbour. A detailed description of the ERICA tool can be found in literature (Beresford et al., 2007; Brown et al., 2008; Larsson, 2008). The tool is based on data gathered from extensive radioecological and dosimetric studies and uses generalised ecosystem representations, also referred to as reference organisms (Beresford et al., 2007). In this context, a reference organism is defined as "a series of entities that provide a basis for the estimation of radiation dose rate to a range of organisms which are typical, or representative, of a contaminated environment" (Beresford et al., 2007).

In this study, the ERICA tool was used to estimate activity concentrations in ten (10) reference organisms captured in the ERICA database, viz. phytoplankton, zooplankton, macroalgae, pelagic/ benthic fishes, mammals, crustaceans, mollusc-bivalves, sea anemones, and polychaete worms. In estimating the activity concentrations in the selected reference organisms, the highest measured activity concentrations in the sediments ( $\mathrm{Bq} \mathrm{kg} \mathrm{kg}^{-1}$ dry wt.) were used as input data to represent "worst case scenarios". Default concentration ratios for the reference organisms in ERICA were then applied. Since, by default, ${ }^{40} \mathrm{~K}$ was not included in the ERICA database, this isotope was also not considered here.

Furthermore, a Tier 2 ERICA assessment was conducted to estimate the total dose rates to biota, applying a default uncertainty factor of 3.0 in the ERICA tool to ensure there will be less than 5\% probability of modelled dose rates exceeding the screening dose rate. Since the magnitude of biological effects varies with different types of ionising radiation (Schmid \& Schrader, 2007), default ERICA weighting factors of 10.0 for alpha, 1.0 for beta/gamma, and 3.0 for low beta radiation were applied to give appropriate weights to the dose rates. As dose rate to biota is a function of the duration of exposure, a default ERICA occupancy factor of 1.0 (i.e., fraction of time that the organism spends at a specified location in its habitat) was assigned to each reference organism, assuming they spend $100 \%$ of the time at their specified locations (i.e. in the water column, on the sediment surface or inside the sediment).

\section{Results and discussion}

\subsection{Concentrations of radionuclides in Tema Harbour sediments}

The activity concentrations of ${ }^{238} \mathrm{U},{ }^{210} \mathrm{~Pb},{ }^{226} \mathrm{Ra},{ }^{228} \mathrm{Ra},{ }^{228} \mathrm{Th}$, ${ }^{232} \mathrm{Th},{ }^{40} \mathrm{~K}$ and ${ }^{137} \mathrm{Cs}$ in the surface sediment samples are shown in Table 1 . The activity concentrations of ${ }^{40} \mathrm{~K}$ were relatively higher than those of the other radionuclides, ranging from 250 to 570 $\mathrm{Bq} \mathrm{kg}{ }^{-1}$ with a mean of $320 \mathrm{~Bq} \mathrm{~kg}{ }^{-1}$. Doyi, Oppon, Glover, Gbeddy, and Kokroko (2013) reported higher levels of ${ }^{40} \mathrm{~K}$ and ${ }^{232} \mathrm{Th}$ for rocks and ore from mines in the Upper East Region of Ghana in the ranges of $950-2800$ and $81-880 \mathrm{~Bq} \mathrm{~kg}{ }^{-1}$, respectively, with a higher mean ${ }^{238} \mathrm{U}$ level of $66( \pm 8) \mathrm{Bq} \mathrm{kg}^{-1}$. The levels of ${ }^{210} \mathrm{~Pb}$ (except at station S15) were markedly higher than those of ${ }^{238} \mathrm{U}$, ${ }^{226} \mathrm{Ra},{ }^{232} \mathrm{Th},{ }^{228} \mathrm{Ra}$ and ${ }^{228} \mathrm{Th}$. Their mean value, $210( \pm 10) \mathrm{Bq} \mathrm{kg}^{-1}$ $\left(\sim 200 \mathrm{~Bq} \mathrm{~kg}^{-1}\right.$ for unsupported $\left.{ }^{210} \mathrm{~Pb}\right)$ is to some extent higher, but comparable to the values of unsupported ${ }^{210} \mathrm{~Pb}$ found by Mahu et al. (2016) in the upper layers of sediment cores sampled in the Amisa (103 $\mathrm{Bq} \mathrm{kg}^{-1}$ ), Sakumo II (157 Bq kg-1) and Volta (123 $\mathrm{Bq} \mathrm{kg}^{-1}$ ) estuaries in Ghana, respectively.

In coastal marine sediments, an excess of ${ }^{228} \mathrm{Th}$ above that supported by the parents ${ }^{232} \mathrm{Th}$ or ${ }^{228} \mathrm{Ra}$ has often been reported, and used for radiometric dating (Koide, Bruland, \& Goldberg, 1973). In the Tema Harbour sediments, the radioactivity concentrations of 
Table 1

Radioactivity concentrations ( $\mathrm{Bq} \mathrm{kg}^{-1} \mathrm{dw}$ ) in Tema Harbour surface sediments and water depth and $\mathrm{E}_{\mathrm{h}}$ at the sampling stations.

\begin{tabular}{|c|c|c|c|c|c|c|c|c|c|c|}
\hline \multirow[t]{2}{*}{ Sampling station } & \multirow[t]{2}{*}{ Water depth (m) } & \multirow[t]{2}{*}{$\mathrm{E}_{\mathrm{h}}(\mathrm{mV})$} & \multicolumn{3}{|c|}{${ }^{238} \mathrm{U}$ series radionuclides } & \multicolumn{3}{|c|}{${ }^{232}$ Th series radionuclides } & \multirow[t]{2}{*}{${ }^{40} \mathrm{~K}$} & \multirow[t]{2}{*}{${ }^{137} \mathrm{Cs}$} \\
\hline & & & ${ }^{238} \mathrm{U}$ & ${ }^{210} \mathrm{~Pb}$ & ${ }^{226} \mathrm{Ra}$ & ${ }^{232} \mathrm{Th}^{\mathrm{a}}$ & ${ }^{228} \mathrm{Ra}$ & ${ }^{228} \mathrm{Th}$ & & \\
\hline S1 & 10 & -96 & $30 \pm 6$ & $230 \pm 10$ & $12 \pm 2$ & $21 \pm 3$ & $18 \pm 2$ & $24 \pm 1$ & $250 \pm 10$ & $1.6 \pm 0.4$ \\
\hline S2 & 7 & -128 & $39 \pm 5$ & $200 \pm 10$ & $11 \pm 1$ & $25 \pm 3$ & $24 \pm 2$ & $26 \pm 1$ & $260 \pm 10$ & $1.7 \pm 0.5$ \\
\hline S3 & 8.5 & -100 & $43 \pm 5$ & $250 \pm 10$ & $13 \pm 1$ & $26 \pm 4$ & $26 \pm 3$ & $25 \pm 1$ & $270 \pm 10$ & $2.0 \pm 0.5$ \\
\hline S4 & 8 & -70 & $40 \pm 4$ & $260 \pm 10$ & $18 \pm 2$ & $32 \pm 4$ & $30 \pm 3$ & $33 \pm 1$ & $350 \pm 10$ & $1.1 \pm 0.5$ \\
\hline S5 & 8 & -65 & $28 \pm 5$ & $250 \pm 10$ & $14 \pm 2$ & $21 \pm 3$ & $19 \pm 2$ & $22 \pm 1$ & $250 \pm 10$ & $1.1 \pm 0.5$ \\
\hline S6 & 8 & -94 & $28 \pm 4$ & $250 \pm 10$ & $17 \pm 2$ & $70 \pm 4$ & $67 \pm 3$ & $72 \pm 1$ & $330 \pm 10$ & $1.3 \pm 0.5$ \\
\hline S7 & 8 & -90 & $28 \pm 4$ & $130 \pm 10$ & $13 \pm 1$ & $37 \pm 3$ & $34 \pm 2$ & $40 \pm 1$ & $460 \pm 20$ & $0.9 \pm 0.5$ \\
\hline S8 & 9 & -80 & $28 \pm 4$ & $210 \pm 10$ & $13 \pm 1$ & $19 \pm 3$ & $18 \pm 2$ & $20 \pm 1$ & $270 \pm 10$ & $1.2 \pm 0.4$ \\
\hline S9 & 8.5 & -80 & $35 \pm 4$ & $290 \pm 10$ & $16 \pm 2$ & $27 \pm 3$ & $24 \pm 2$ & $29 \pm 1$ & $290 \pm 10$ & $2.3 \pm 0.5$ \\
\hline S10 & 9.5 & -78 & $32 \pm 4$ & $230 \pm 10$ & $15 \pm 1$ & $26 \pm 3$ & $24 \pm 2$ & $28 \pm 1$ & $350 \pm 10$ & $1.1 \pm 0.4$ \\
\hline S11 & 8.5 & -70 & $21 \pm 4$ & $110 \pm 10$ & $10 \pm 1$ & $38 \pm 3$ & $36 \pm 2$ & $39 \pm 1$ & $570 \pm 20$ & $0.5 \pm 0.3$ \\
\hline S12 & 9 & -50 & $47 \pm 7$ & $130 \pm 10$ & $14 \pm 1$ & $44 \pm 4$ & $44 \pm 3$ & $43 \pm 1$ & $390 \pm 20$ & $2.2 \pm 0.5$ \\
\hline S13 & 7.5 & -70 & $36 \pm 3$ & $240 \pm 10$ & $17 \pm 1$ & $29 \pm 3$ & $27 \pm 2$ & $31 \pm 1$ & $330 \pm 10$ & $1.1 \pm 0.4$ \\
\hline S14 & 10 & -95 & $42 \pm 4$ & $280 \pm 10$ & $16 \pm 1$ & $28 \pm 3$ & $25 \pm 2$ & $31 \pm 1$ & $330 \pm 10$ & $1.4 \pm 0.4$ \\
\hline S15 & 3 & -400 & $24 \pm 4$ & $20 \pm 5$ & $16 \pm 1$ & $37 \pm 3$ & $36 \pm 2$ & $38 \pm 1$ & $330 \pm 10$ & $<0.3$ \\
\hline S16 & 4 & -210 & $26 \pm 5$ & $230 \pm 10$ & $13 \pm 2$ & $34 \pm 3$ & $35 \pm 2$ & $32 \pm 1$ & $310 \pm 10$ & $1.9 \pm 0.5$ \\
\hline S17 & 5 & -140 & $32 \pm 4$ & $230 \pm 10$ & $13 \pm 2$ & $25 \pm 3$ & $21 \pm 2$ & $28 \pm 1$ & $310 \pm 10$ & $1.5 \pm 0.4$ \\
\hline S18 & 8 & -115 & $42 \pm 5$ & $310 \pm 20$ & $14 \pm 1$ & $23 \pm 3$ & $22 \pm 2$ & $23 \pm 1$ & $270 \pm 10$ & $1.9 \pm 0.4$ \\
\hline S19 & 8 & -110 & $35 \pm 6$ & $240 \pm 10$ & $11 \pm 2$ & $24 \pm 4$ & $23 \pm 3$ & $25 \pm 1$ & $300 \pm 10$ & $1.6 \pm 0.5$ \\
\hline S20 & 8 & -100 & $27 \pm 4$ & $170 \pm 10$ & $20 \pm 1$ & $26 \pm 3$ & $24 \pm 2$ & $27 \pm 1$ & $300 \pm 10$ & $1.4 \pm 0.4$ \\
\hline S21 & 8 & -90 & $41 \pm 5$ & $170 \pm 10$ & $18 \pm 1$ & $28 \pm 3$ & $27 \pm 2$ & $29 \pm 1$ & $300 \pm 10$ & $1.5 \pm 0.5$ \\
\hline Average & - & - & $34 \pm 5$ & $210 \pm 10$ & $14 \pm 1$ & $30 \pm 3$ & $29 \pm 2$ & $31 \pm 1$ & $320 \pm 10$ & $1.5 \pm 0.5$ \\
\hline
\end{tabular}

Errors are 1 standard deviation from counting statistics

a ${ }^{232} \mathrm{Th}$ activities are estimated from grand-daughters activities.

${ }^{232} \mathrm{Th},{ }^{228} \mathrm{Ra}$ and ${ }^{228} \mathrm{Th}$ were comparable within the involved uncertainties. Activity concentrations of ${ }^{137} \mathrm{Cs}$ in the sediments were markedly low, varying from $<0.3$ to $2.3 \mathrm{~Bq} \mathrm{~kg}^{-1}$ with a mean of 1.5 $\mathrm{Bq} \mathrm{kg}^{-1}$. These values are comparable to those reported by Mahu et al. (2016) for the surface layers of estuarine sediments from Ghana (in the range $0-7 \mathrm{~Bq} \mathrm{~kg}^{-1}$ ). The low ${ }^{137} \mathrm{Cs}$ levels suggest low atmospheric fallout in the study area, coupled with natural decay following its deposition (Livingston \& Povinec, 2000; Pfitzner, Brunskill, \& Zagorskis, 2004) or remobilisation from sediment into seawater (Sugandhi et al., 2014). Thus, Junge et al. (2010) have reported ${ }^{137} \mathrm{Cs}$ concentrations in the range $0.5-6.5 \mathrm{~Bq} \mathrm{~kg}^{-1}$ in farmland soils from Nigeria.

The levels of ${ }^{210} \mathrm{~Pb}\left(20 \pm 5 \mathrm{~Bq} \mathrm{~kg}{ }^{-1}\right)$ and ${ }^{137} \mathrm{Cs}\left(<0.3 \mathrm{~Bq} \mathrm{~kg}^{-1}\right)$ in the shallow station of the Canoe Basin (S15) were very low compared to the levels found at the remaining stations. Several mechanisms are involved in the distribution of radionuclides in the harbour such as hydrodynamics, waves, tides, and vessel movements and dredging. The Canoe Basin is receives sediments from mixed sources including sand bars bordering one of its sides. In May 2013, maintenance dredging was carried out in the Canoe Basin to ensure safer navigation and increase berthing capacity for the operation of canoes. Dredging can potentially remove contaminated sediments while influx of sand may cause dilution, and may partly account for the low radioactivity levels of ${ }^{210} \mathrm{~Pb}$ and ${ }^{137} \mathrm{Cs}$ at S16. In the Main Harbour, the ${ }^{210} \mathrm{~Pb}$ levels at stations S7 $\left(130 \pm 10 \mathrm{~Bq} \mathrm{~kg}{ }^{-1}\right), \mathrm{S} 11\left(110 \pm 10 \mathrm{~Bq} \mathrm{~kg}{ }^{-1}\right)$ and $\mathrm{S} 12(130 \pm 10$ $\mathrm{Bq} \mathrm{kg}{ }^{-1}$ ) were relatively lower than those at the other stations. This may partly be due to a dilution effect of the discharges of industrial wastewater and sand channelled into the harbour at S7, which can also affect neighbouring areas such as stations S12 and S11. On the contrary, Table 1 shows that these same three stations (S7, S11 and S12) recorded relatively higher levels of ${ }^{40} \mathrm{~K}$, possibly due to organic enrichment in sediments as a result of the waste water discharges.

The ratios of ${ }^{238} \mathrm{U} /{ }^{226} \mathrm{Ra},{ }^{238} \mathrm{U} /{ }^{210} \mathrm{~Pb}$ and ${ }^{210} \mathrm{~Pb} /{ }^{226} \mathrm{Ra}$ were in the ranges of $1.4-3.5,0.1-0.4$ and $1.3-22.4$, respectively. The departures of these ratios from 1.0 indicate disequilibria, a general characteristic of marine surface sediments previously observed by others (Chen \& Huh, 1999; Koide et al., 1973), which may be caused by anthropogenic influences (Al-Trabulsy et al., 2011; El Mamoney \& Khater, 2004; Nyarko et al., 2011; UNSCEAR, 2000). The origin of the excess ${ }^{210} \mathrm{~Pb}$ found in sediments is well known, and it is the basis of the ${ }^{210} \mathrm{~Pb}$-based radiometric method for dating recent sediments (Mabit et al., 2014). On the contrary, the observed disequilibria between ${ }^{238} \mathrm{U}$ (derived from ${ }^{234} \mathrm{Th}$ activity, see Section 2.3 ) and ${ }^{226} \mathrm{Ra}$ may be ascribed to differences in geochemical behaviour of the radionuclides (Koide et al., 1973). ${ }^{226} \mathrm{Ra}$ and ${ }^{238} \mathrm{U}$ are known for their different sorption and mobility characteristics; ${ }^{226} \mathrm{Ra}$ and ${ }^{238} \mathrm{U}$ are less particle-reactive than Th isotopes with greater tendency to diffuse from sediments into the surrounding seawater (Chen \& Huh, 1999; Sirelkhatim et al., 2008; Sugandhi et al., 2014). The higher levels of ${ }^{238} \mathrm{U}$ relative to ${ }^{226} \mathrm{Ra}$ in the sediments may be due to diffusion and loss of Ra from sediment owing to its higher solubility in seawater or higher leachability of ${ }^{226} \mathrm{Ra}$ from the harbour sediments than ${ }^{238} \mathrm{U}-{ }^{234} \mathrm{Th}$. At the time of sampling, the bottom water was anoxic, having $E_{h}$ values in the range of -50 to $-400 \mathrm{mV}$ (Table 1 ), which may enhance immobilisation and precipitation of ${ }^{238} \mathrm{U}$ in the sediments (El Mamoney \& Khater, 2004). Mohamed, Mahmood, Ahmad, and Ishak (2010) reported ${ }^{228} \mathrm{Ra} /{ }^{226} \mathrm{Ra}$ activity ratios in the range $1.2-2.9$ with ${ }^{238} \mathrm{U} /{ }^{226} \mathrm{Ra}$ activity ratios in the range 1.1-5.6 for southern South China Sea surface sediments, which compare well with the ranges 1.4-3.9 and $1.6-3.5$ found in this work (Table 1 ) for ${ }^{228} \mathrm{Ra} /{ }^{226} \mathrm{Ra}$ and ${ }^{238} \mathrm{U} /{ }^{226} \mathrm{Ra}$ activity ratios, respectively.

The mean radioactivity levels in the Tema Harbour sediments and levels reported for other areas are shown in Table 2. With the exception of Labadi that recorded higher levels of ${ }^{226} \mathrm{Ra}$ and ${ }^{232} \mathrm{Th}$, the mean radioactivity levels in the Tema Harbour sediments were generally higher than those reported in sediments from other areas, i.e. Chorkor, James Town, Nungua, Kokrobite, Teshie and Weija of the Greater Accra coast of Ghana (Amekudzie et al., 2011). Nyarko et al. (2011) also reported lower activity concentrations of ${ }^{210} \mathrm{~Pb}$ in beach sand samples along the Ghana coast ranging from 1.6 up to $4.5 \mathrm{~Bq} \mathrm{~kg}^{-1}$ and ${ }^{137} \mathrm{Cs}$ concentrations below the detection limit of $0.4 \mathrm{~Bq} \mathrm{~kg}{ }^{-1}$. The mean radioactivity levels in the Tema Harbour sediments were also higher than the levels reported for the Mediterranean coast of Egypt (Higgy, 2000), but were comparable to 
Table 2

Radioactivity levels in Tema Harbour surface sediments and levels reported in sediments from other areas of the world.

\begin{tabular}{|c|c|c|c|c|c|c|c|c|c|}
\hline \multirow[t]{2}{*}{ Sampling station } & \multicolumn{3}{|c|}{$\begin{array}{l}{ }^{238} \mathrm{U} \text { series } \\
\text { radionuclides } \\
\left(\mathrm{Bq} \mathrm{kg}^{-1} \mathrm{dw}\right)\end{array}$} & \multicolumn{3}{|c|}{$\begin{array}{l}{ }^{232} \mathrm{Th} \text { series } \\
\text { radionuclides } \\
\left(\mathrm{Bq} \mathrm{kg}{ }^{-1} \mathrm{dw}\right)\end{array}$} & \multirow[t]{2}{*}{$\begin{array}{l}{ }^{40} \mathrm{~K} \\
\left(\mathrm{~Bq} \mathrm{~kg}{ }^{-1} \mathrm{dw}\right)\end{array}$} & \multirow[t]{2}{*}{$\begin{array}{l}{ }^{137} \mathrm{Cs} \\
\left(\mathrm{Bq} \mathrm{kg}^{-1} \mathrm{dw}\right)\end{array}$} & \multirow[t]{2}{*}{ Reference } \\
\hline & ${ }^{238} \mathrm{U}$ & ${ }^{210} \mathrm{~Pb}$ & ${ }^{226} \mathrm{Ra}$ & ${ }^{232} \mathrm{Th}$ & ${ }^{228} \mathrm{Ra}$ & ${ }^{228} \mathrm{Th}$ & & & \\
\hline \multicolumn{10}{|l|}{ Ghana coast } \\
\hline Chorkor & - & - & 1.42 & 1.49 & - & - & 21.31 & - & Amekudzie et al. (2011) \\
\hline James Town & - & - & 0.82 & 1.04 & - & - & 14.67 & - & Amekudzie et al. (2011) \\
\hline Labadi & - & - & 140.8 & 732.6 & - & - & 43.97 & - & Amekudzie et al. (2011) \\
\hline Nungua & - & - & 4.05 & 8.64 & - & - & 41.17 & - & Amekudzie et al. (2011) \\
\hline Kokrobite & - & - & 3.74 & 6.63 & - & - & 17.76 & - & Amekudzie et al. (2011) \\
\hline Teshie & - & - & 2.85 & 9.66 & - & - & 61.01 & - & Amekudzie et al. (2011) \\
\hline Weija & - & - & 0.62 & 0.17 & - & - & 8.6 & - & Amekudzie et al. (2011) \\
\hline Tema Habour & 34 & 210 & 14 & 30 & 29 & 31 & 325 & 1.5 & This study \\
\hline \multicolumn{10}{|l|}{ Other areas } \\
\hline Port Sudan, Sudan & - & - & 11.05 & - & 10.35 & - & 311 & 7.02 & Sam et al. (1998) \\
\hline Sawakin Harbour, Sudan & - & - & 12.61 & - & 6.18 & - & 192 & 4.51 & Sam et al. (1998) \\
\hline Patras Harbour, Greece & - & - & 22.6 & 24.5 & - & - & 497 & 3.1 & Papaefthymiou et al. (2007) \\
\hline Mumbai Harbour, India & - & - & 10.6 & & 12.7 & & 436 & 21.6 & Sugandhi et al. (2014) \\
\hline Karachi Harbour, Pakistan & & & 23.9 & - & 23.5 & - & 527 & $<1.3$ & Akram et al. (2006) \\
\hline Saudi coast, Gulf of Aqaba & 16.97 & - & 11 & 22 & 19 & - & 641 & 3.5 & Al-Trabulsy et al. (2011) \\
\hline Red Sea coast, Egypt & 25.5 & 26 & 24.6 & - & - & - & 427.5 & - & El Mamoney and Khater (2004) \\
\hline Mediterranean coast, Egypt & 8.8 & - & 5 & 2.1 & - & - & 46 & & Higgy (2000) \\
\hline Caspian Sea coast, Iran & 177 & - & - & 117 & - & - & 1085 & 131 & Abdi et al. (2009) \\
\hline Malaysia coast, South China Sea & 45.9 & & 27.7 & 73.3 & 66.2 & - & - & - & Mohamed et al. (2010) \\
\hline World average & $35^{\mathrm{a}}$ & $25^{\mathrm{b}}$ & $25^{\mathrm{b}, \mathrm{c}, \mathrm{d}, \mathrm{e}}$ & $25^{\mathrm{c}, \mathrm{e}}$ & - & - & $373^{\mathrm{d}, \mathrm{e}}$ & - & $\begin{array}{l}\text { as SureshGandhi et al. (2014); }{ }^{\text {b }} \text { Nyarko et al. (2011); } \\
{ }^{\mathrm{c}} \text { Qureshi et al. (2014); }{ }^{\mathrm{d}} \text { Kurnaz et al. (2007); } \\
{ }^{\text {e}} \text { Sugandhi et al. (2014) }\end{array}$ \\
\hline
\end{tabular}

levels reported for the Saudi coast of the Gulf of Aqaba, except for their higher ${ }^{40} \mathrm{~K}$ (Al-Trabulsy et al., 2011); the Red Sea coast of Egypt (El Mamoney \& Khater, 2004), Port Sudan and Sawakin Harbour of Sudan (Sam et al., 1998), Patras Harbour, Greece (Papaefthymiou et al., 2007), Mumbai Harbour, India (Sugandhi et al., 2014), and the Karachi Harbour, Pakistan (Sugandhi et al., 2014). The mean radioactivity levels of ${ }^{238} \mathrm{U},{ }^{232} \mathrm{Th},{ }^{40} \mathrm{~K}$ and ${ }^{137} \mathrm{Cs}$ in the Tema Harbour sediments were, however, much lower than those found in polluted sediments from the Caspian Sea coast of Iran (Abdi, Hassanzadeh, Kamali, \& Raji, 2009). Mohamed et al. (2010) found comparatively higher levels of ${ }^{226} \mathrm{Ra},{ }^{228} \mathrm{Ra},{ }^{238} \mathrm{U}$ and ${ }^{232} \mathrm{Th}$ for surface sediments from the Malaysia coast of the southern South China Sea. Generally, the mean radioactivity levels in the Tema Harbour sediments were comparable to the reported worldwide averages (Nyarko et al., 2011; Papaefthymiou et al., 2007; Qureshi et al., 2014; SureshGandhi et al., 2014), except for ${ }^{210} \mathrm{~Pb}$ which was almost an order of magnitude higher than its grandparent ${ }^{226} \mathrm{Ra}$, due to the presence of unsupported ${ }^{210} \mathrm{~Pb}$.

\subsection{Radiological significance of Tema Harbour sediment radioactivity levels}

The calculated hazard indices for the Tema Harbour sediments and hazard indices reported for sediments from other areas of the world are presented in Table 3. The ranges (means) of $D, \mathrm{Ra}_{\mathrm{eq}}, H_{e x}$, AGDE, and AEDE for the Tema Harbour sediments were 29-64 nGy.h ${ }^{-1}$ (39 nGy.h ${ }^{-1}$ ), 61-142 Bq kg-1 (82.7 Bq kg-1),

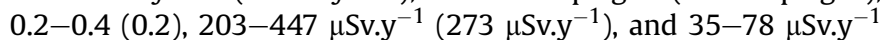
$\left(47 \mu S v . y^{-1}\right)$, respectively. These mean $D, R_{e}$ eq,$H_{e x}$, AGDE, and AEDE values were below the recommended values, although there were a few areas where the measured $\mathrm{Ra}_{\mathrm{eq}}$ (i.e. S4, S6, S7, S11, S12 and S15), ADGE (i.e. S6, S7, S11, S12 and S15) and AEDE (i.e. S6) exceeded the recommended values. Thus, the radioactivity levels in the harbour sediments are generally of little radiological concern for human health.

Compared to this study, Amekudzie et al. (2011) reported higher mean $D\left(77 \mathrm{nGy} \cdot \mathrm{h}^{-1}\right)$ and $H_{e x}(0.5)$, but lower mean $\mathrm{Ra}_{\mathrm{eq}}\left(9 \mathrm{~Bq} \mathrm{~kg}{ }^{-1}\right)$ values for sediments from Chorkor, James Town, Nungua, Kokrobite, Teshie and Weija along the Greater Accra coast of Ghana (Table 3). Comparable mean values of $D\left(42 \mathrm{nGy} \cdot \mathrm{h}^{-1}\right)$ and $\mathrm{Ra}_{\mathrm{eq}}(101$ $\mathrm{Bq} \mathrm{kg}{ }^{-1}$ ) were reported for the Red Sea coast of Egypt by El Mamoney and Khater (2004), while a lower mean $D$ value of $5.5 \mathrm{nGy} \cdot \mathrm{h}^{-1}$ was reported for the Mediterranean coast of Egypt by Higgy (2000). Higher mean values of $D\left(63 \mathrm{nGy} \cdot \mathrm{h}^{-1}\right), \mathrm{Ra}_{\mathrm{eq}}(176$ $\mathrm{Bq} \mathrm{kg}^{-1}$ ) and $H_{e x}(0.5)$ were reported for sediments from the Caspian Sea coast by Abdi et al. (2009), while a lower mean $H_{e x}$ value of 0.1 was reported for the Saudi coast of the Gulf of Aqaba by AlTrabulsy et al. (2011).

\subsection{Radioecological significance of Tema Harbour sediment radioactivity}

Table 4 presents the estimated radioactivity levels in the selected reference organisms. Generally, biota exhibited potentially higher accumulation levels of ${ }^{210} \mathrm{~Pb}\left(1.18-570 \mathrm{~Bq} \mathrm{~kg}^{-1}\right)$ relative to the other radionuclides $\left(0-0.05\right.$ for ${ }^{137} \mathrm{Cs}$; $0.82-14.4$ for $\mathrm{Ra}$; $0.01-6.60$ for $\mathrm{Th}$, and $0.06-17.5 \mathrm{~Bq} \mathrm{~kg}^{-1}$ for ${ }^{238} \mathrm{U}$ ), possibly reflecting the relatively higher levels of ${ }^{210} \mathrm{~Pb}$ in the sediments. Thus, sediments may be an important source of ${ }^{210} \mathrm{~Pb}$ exposure to biota. The levels of ${ }^{210} \mathrm{~Pb}$ were markedly high in phytoplankton, exceeding the levels in the sediments. This is an indication of a high potential for ${ }^{210} \mathrm{~Pb}$ bioaccumulation by phytoplankton as has been reported by Hassona et al. (2008). Overall, phytoplankton exhibited the highest potential for radionuclide exposure from sediment, suggesting that it could be a good bioindicator for monitoring of radionuclide contamination in the Tema Harbour. Apart from the ${ }^{210} \mathrm{~Pb}$ levels in phytoplankton, the radioactivity levels in all the reference organisms were generally low compared to the levels in the sediments. This indicates that the radionuclides associate mainly with the sediments, despite their potential for bioaccumulation (Hassona et al., 2008; Sirelkhatim et al., 2008). This supports the view that sediments are the major sinks for radionuclides in aquatic ecosystems (Sugandhi et al., 2014). The very low activity levels of Th and ${ }^{137} \mathrm{Cs}$ in biota suggest that sediments may 
Table 3

Calculated $D, \mathrm{Ra}_{\mathrm{eq}}, H_{e x}$, AGDE and AEDE for Tema Harbour surface sediments and sediments from other parts of the world as well as recommended values.

\begin{tabular}{|c|c|c|c|c|c|c|}
\hline & $\begin{array}{l}D \\
\left(\mathrm{nGy} \cdot \mathrm{h}^{-1}\right)\end{array}$ & $\begin{array}{l}\mathrm{Ra}_{\mathrm{eq}} \\
\left(\mathrm{Bq} \mathrm{kg}^{-1}\right)\end{array}$ & $H_{e x}$ & $\begin{array}{l}\text { AGDE } \\
\left(\mu \mathrm{Sv}_{\mathrm{y}^{-1}}\right)\end{array}$ & $\begin{array}{l}\text { AEDE } \\
\left(\mu \mathrm{Sv} \mathrm{y}^{-1}\right)\end{array}$ & Reference \\
\hline \multicolumn{7}{|l|}{ Tema Harbour } \\
\hline S1 & 29 & 61 & 0.2 & 203 & 35 & \multirow[t]{22}{*}{ This study } \\
\hline $\mathrm{S} 2$ & 31 & 67 & 0.2 & 220 & 38 & \\
\hline S3 & 33 & 70 & 0.2 & 232 & 40 & \\
\hline S4 & 42 & 90 & 0.2 & 297 & 51 & \\
\hline S5 & 29 & 63 & 0.2 & 208 & 36 & \\
\hline S6 & 64 & 142 & 0.4 & 447 & 78 & \\
\hline S7 & 48 & 101 & 0.3 & 339 & 58 & \\
\hline S8 & 29 & 61 & 0.2 & 204 & 35 & \\
\hline S9 & 36 & 76 & 0.2 & 251 & 44 & \\
\hline S10 & 37 & 79 & 0.2 & 265 & 46 & \\
\hline S11 & 51 & 108 & 0.3 & 367 & 63 & \\
\hline S12 & 49 & 106 & 0.3 & 348 & 60 & \\
\hline S13 & 39 & 84 & 0.2 & 277 & 48 & \\
\hline S14 & 38 & 82 & 0.2 & 270 & 47 & \\
\hline S15 & 44 & 94 & 0.3 & 308 & 53 & \\
\hline S16 & 39 & 85 & 0.2 & 278 & 48 & \\
\hline S17 & 34 & 72 & 0.2 & 240 & 41 & \\
\hline S18 & 31 & 67 & 0.2 & 222 & 38 & \\
\hline S19 & 32 & 68 & 0.2 & 229 & 39 & \\
\hline S20 & 37 & 80 & 0.2 & 263 & 46 & \\
\hline S21 & 38 & 81 & 0.2 & 267 & 46 & \\
\hline Mean & 39 & 83 & 0.2 & 273 & 47 & \\
\hline \multicolumn{7}{|l|}{ Mean values for other areas } \\
\hline Caspian Sea coast, Iran & 63 & 176 & 0.5 & - & - & Abdi et al. (2009) \\
\hline Red Sea coast, Egypt & 42 & 101 & - & - & - & El Mamoney and Khater (2004) \\
\hline Saudi coast, Gulf of Aqaba & - & - & 0.1 & - & - & Al-Trabulsy et al. (2011) \\
\hline Mediterranean coast, Egypt & 5.5 & - & - & - & - & Higgy (2000) \\
\hline Ghana coast & 77 & 9 & 0.5 & - & 0.1 & Amekudzie et al. (2011) \\
\hline Recommended value & $55^{\mathrm{a}, \mathrm{b}}$ & $89^{a}$ & $1.0^{\mathrm{c}}$ & $300^{c}$ & $70^{c}$ & \\
\hline
\end{tabular}

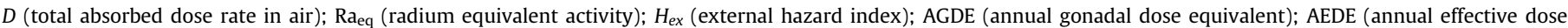

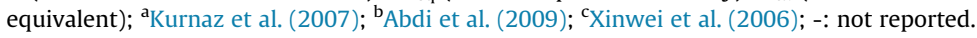

Table 4

Highest radioactivity concentrations in Tema Harbour sediments and ERICA-derived radioactivity concentrations in reference organisms.

\begin{tabular}{|c|c|c|c|c|c|c|c|c|c|c|}
\hline & \multirow[t]{2}{*}{ Sediment $\left(\mathrm{Bq} \mathrm{kg}^{-1} \mathrm{dw}\right)$} & \multicolumn{9}{|c|}{ Reference organisms (Bq kg ${ }^{-1}$ fresh weight) } \\
\hline & & Phytoplankton & Zooplankton & Macroalgae & $\begin{array}{l}\text { Pelagic/Benthic } \\
\text { fishes }\end{array}$ & Mammals & Crustaceans & $\begin{array}{l}\text { Mollusc- } \\
\text { bivalves }\end{array}$ & $\begin{array}{l}\text { Sea } \\
\text { anemones }\end{array}$ & $\begin{array}{l}\text { Polychaete } \\
\text { worms }\end{array}$ \\
\hline${ }^{137} \mathrm{Cs}$ & 2.3 & 0 & 0.03 & 0.02 & 0.02 & 0.05 & 0.01 & 0.01 & 0.05 & 0.04 \\
\hline${ }^{\mathrm{a}} \mathrm{Ra}$ & 67 & 14.4 & 1.02 & 1.13 & 1.76 & 2.06 & 1.08 & 0.82 & 1.76 & 1.76 \\
\hline${ }^{210} \mathrm{~Pb}$ & 314 & 570 & 20 & 1.18 & 38.9 & 22.4 & 24.8 & 7.43 & 38.9 & 47.2 \\
\hline${ }^{\mathrm{b}} \mathrm{Th}$ & 72 & 6.60 & 0.06 & 0.04 & 0.01 & 0.02 & 0.35 & 0.02 & 0.02 & 0.02 \\
\hline${ }^{238} U$ & 47 & 3.85 & 0.07 & 1.47 & 0.16 & 0.16 & 0.06 & 0.57 & 17.5 & 17.5 \\
\hline
\end{tabular}

${ }^{\mathrm{a}} \mathrm{Ra}$ is for both ${ }^{226} \mathrm{Ra}$ and ${ }^{228} \mathrm{Ra}$.

b Th for both ${ }^{232}$ Th and ${ }^{228}$ Th.

not be a major exposure pathway of these radionuclides to biota in the harbour.

The ERICA-derived dose rates to biota are presented in Table 5. It shows that phytoplankton could potentially receive higher dose rates from sediment radioactivity than the other reference organisms, which corresponds to its higher bioaccumulation potential for radionuclides (Table 4). The total dose rate to phytoplankton slightly exceeded the typical maximum value in the ERICA database (see Table 5). Whereas the total dose rate to pelagic fishes was similar to the typical minimum, that of crustaceans slightly exceeded the typical minimum value, but fell below the typical average value. In the case of zooplankton, macroalgae, benthic fishes, mammal, mollusc-bivalves and polychaete worms, the total dose rates fell below their ERICA typical minimum values (Table 5). The total dose rates to all the reference organisms fell below the screening dose rate of $400 \mu \mathrm{Gy} \cdot \mathrm{h}^{-1}$, proposed by the International Atomic Energy Agency (IAEA) and the United Nations Scientific Committee on the Effects of Atomic Radiation (UNSCEAR) as the dose rate below which harmful effects are unlikely to occur in organisms.

It is worthy to note that the ERICA tool was used in this study as a screening tool to provide estimates of the radioactivity levels in biota and associated total dose rates rather than their accurate prediction. Furthermore, the estimated total dose rates to biota may be underestimated since they were based on the radioactivity concentrations of only ${ }^{238} \mathrm{U},{ }^{210} \mathrm{~Pb},{ }^{226} \mathrm{Ra},{ }^{228} \mathrm{Ra},{ }^{228} \mathrm{Th},{ }^{232} \mathrm{Th}$ and ${ }^{137}$ Cs. Measurement of radioactivity levels in different environmental matrices such as sediments, water and biota from the harbour will be important to validate the predictive ability of the ERICA modelling tool for the Tema Harbour ecosystem and is, therefore, recommended for future studies.

\section{Conclusions}

The radioactivity levels of ${ }^{238} \mathrm{U},{ }^{210} \mathrm{~Pb},{ }^{226} \mathrm{Ra},{ }^{232} \mathrm{Th},{ }^{228} \mathrm{Ra},{ }^{228} \mathrm{Th}$, ${ }^{40} \mathrm{~K}$ and ${ }^{137} \mathrm{Cs}$ in surface sediment from the Tema Harbour in Ghana 
Table 5

ERICA-derived total dose rates to reference organisms and typical maximum, minimum, and average values $\left(\mu \mathrm{Gy} \cdot \mathrm{h}^{-1}\right)$ in the ERICA database.

\begin{tabular}{|c|c|c|c|c|}
\hline Reference organism & Total Dose rate & Typical average dose rate & Typical minimum dose rate & Typical maximum dose rate \\
\hline Phytoplankton & 2.11 & 0.38 & 0.13 & 2.00 \\
\hline Zooplankton & 0.06 & 0.94 & 0.25 & 5.20 \\
\hline Pelagic fish & 0.09 & 0.42 & 0.08 & 3.70 \\
\hline Mammal & 0.10 & 1 & 0.23 & 5.80 \\
\hline Macroalgae & 0.13 & 0.87 & 0.52 & 1.40 \\
\hline Benthic fish & 0.12 & 0.58 & 0.24 & 1.20 \\
\hline Crustacean & 0.16 & 0.59 & 0.12 & 1.90 \\
\hline Mollusc-bivalve & 0.09 & 2 & 0.98 & 5.60 \\
\hline Sea anemones & 0.54 & 4.20 & 1.90 & 8.80 \\
\hline Polychaete worm & 0.58 & 1.6 & 0.94 & 2.5 \\
\hline
\end{tabular}

have been assessed for the first time. The levels of ${ }^{40} \mathrm{~K}$ and ${ }^{210} \mathrm{~Pb}$ were relatively higher than the levels of the other radionuclides in the Tema Harbour sediments. Large disequilibria between ${ }^{238} \mathrm{U}$ and ${ }^{226} \mathrm{Ra}$ were found, attributable to the dynamics of the radionuclides in the harbour. Apart from ${ }^{210} \mathrm{~Pb}$, the radioactivity concentrations of the natural radionuclides in the Tema Harbour sediments were comparable to worldwide average values. Evaluation of total absorbed dose rate in air $(D)$, radium equivalent activity ( $\left.R \mathrm{a}_{\mathrm{eq}}\right)$, external hazard index $\left(H_{e x}\right)$, annual gonadal dose equivalent (AGDE) and annual effective dose equivalent (AEDE) indicate that the potential dose rates to human from the sediment radioactivity levels may not present significant risks to human health. Moreover, the potential dose rates to biota derived from the ERICA assessment indicate low ecological risks associated with the radioactivity levels in the harbour sediments. This study provides baseline information on radioactivity levels in the Tema Harbour sediments for comparison to future monitoring studies.

\section{Acknowledgements}

This study was conducted under the Netherlands Fellowship Programme (NFP-PhD. 12/316) with financial support from the Office of Research, Innovation and Development (ORID) of the University of Ghana under the Faculty Development Fund (UGFD/7/ 2012-2013/004). The authors wish to express their gratitude to Prof. J.M. Abril (University of Seville, Spain) for reading through the manuscript and his suggestions. We acknowledge the laboratory staff of the Department of Marine and Fisheries Sciences at the University of Ghana for assisting in the field work and Mr. Bashara Ahmed (CERSGIS, University of Ghana) for generating the map of the study area. We also thank the Ghana Ports and Harbours Authority for permitting us to conduct this study.

\section{References}

Abdi, M. R., Hassanzadeh, S., Kamali, M., \& Raji, H. R. (2009). ${ }^{238}$ U, ${ }^{232}$ Th, ${ }^{40} \mathrm{~K}$ and ${ }^{137} \mathrm{Cs}$ activity concentrations along the southern coast of the Caspian Sea, Iran. Marine Pollution Bulletin, 58(5), 658-662.

Akram, M., Qureshi, R., Ahmad, N., Solaija, T, Mashiatullah, A., Afzal, M., et al. (2006). Concentration of natural and artificial radionuclides in bottom sediments of Karachi harbour/Manora channel, Pakistan coast (Arabian sea). Journal of the Chemical Society of Pakistan, 28(3), 306-312.

Al-Trabulsy, H., Khater, A., \& Habbani, F. (2011). Radioactivity levels and radiological hazard indices at the Saudi coastline of the Gulf of Aqaba. Radiation Physics and Chemistry, 80(3), 343-348.

Amekudzie, A., Emi-Reynolds, G., Faanu, A., Darko, E., Awudu, A., Adukpo, O., et al. (2011). Natural radioactivity concentrations and dose assessment in shore sediments along the coast of Greater Accra, Ghana. World Applied Sciences Journal, 13(11), 2338-2343.

Beresford, N., Brown, J., Copplestone, D., Garnier-Laplace, J., Howard, B., Larsson, C.M., et al. (2007). D-ERICA: An integrated approach to the assessment and management of environmental risk from ionising radiation. Description of purpose, Methodology and Application, 82.

Broecker, W. (1982). Geochemical tracers and ocean circulation. Palisades, NY: Lamont-Doherty Geological Observatory, 434-450.

Brown, J., Alfonso, B., Avila, R., Beresford, N. A., Copplestone, D., Pröhl, G., et al.
2008). The ERICA tool. Journal of Environmental Radioactivity 99(9), 1371-1383.

Chen, H. Y., \& Huh, C. A. (1999). ${ }^{232} \mathrm{Th}-{ }^{228} \mathrm{Ra}-{ }^{228}$ Th disequilibrium in East China Sea sediments. Journal of Environmental Radioactivity, 42(1), 93-100.

Divine, C. E., \& McDonnell, J. J. (2005). The future of applied tracers in hydrogeology. Hydrogeology Journal, 13(1), 255-258.

Doyi, I., Oppon, O., Glover, E., Gbeddy, G., \& Kokroko, W. (2013). Assessment of occupational radiation exposure in underground artisanal gold mines in Tongo, Upper East Region of Ghana. Journal of Environmental Radioactivity, 126, 77-82.

El Mamoney, M., \& Khater, A. E. (2004). Environmental characterization and radioecological impacts of non-nuclear industries on the Red Sea coast. Journal of Environmental Radioactivity, 73(2), 151-168.

Hassona, R. K., Sam, A. K., Osman, O. I., Sirelkhatim, D. A., \& LaRosa, J. (2008). Assessment of committed effective dose due to consumption of Red Sea cora reef fishes collected from the local market (Sudan). Science of the Total Environment, 393(2-3), 214-218.

Hernández, J.-M. A. (2016). A ${ }^{210} \mathrm{~Pb}$-based chronological model for recent sediments with random entries of mass and activities: Model development. Journal of Environmental Radioactivity, 151, 64-74.

Higgy, R. (2000). Natural radionuclides and plutonium isotopes in soil and shore sediments on Alexandria Mediterranean Sea coast of Egypt. Radiochimica Acta 88(1), 47-54.

Junge, B., Mabit, L. Dercon, G., Walling D., Abaidoo, R., Chikoye, D., et al. (2010) First use of the 137 Cs technique in Nigeria for estimating medium-term soil redistribution rates on cultivated farmland. Soil and Tillage Research, 110(2) $211-220$.

Kam, E., \& Bozkurt, A. (2007). Environmental radioactivity measurements in Kastamonu region of northern Turkey. Applied Radiation and Isotopes, 65(4) $440-444$.

Koide, M., Bruland, K. W., \& Goldberg, E. D. (1973). Th-228/Th-232 and Pb-210 geochronologies in marine and lake sediments. Geochimica et Cosmochimica Acta, 37(5), 1171-1187.

Kpeglo, D., Mantero, J., Darko, E., Emi-Reynolds, G., Faanu, A., Manjón, G., et al. (2016). Radiochemical characterization of produced water from two production offshore oilfields in Ghana. Journal of Environmental Radioactivity, 152, 35-45.

Kumar, A., Karpe, R., Rout, S., Joshi, V., Singhal, R. K., \& Ravi, P. M. (2013). Spatia distribution and accumulation of ${ }^{226} \mathrm{Ra},{ }^{228} \mathrm{Ra},{ }^{40} \mathrm{~K}$ and ${ }^{137} \mathrm{Cs}$ in bottom sediments of Mumbai Harbour Bay. Journal of Radioanalytical and Nuclear Chemistry 295(2), 835-839.

Kurnaz, A., Küçükömeroğlu, B., Keser, R., Okumusoglu, N., Korkmaz, F., Karahan, G., et al. (2007). Determination of radioactivity levels and hazards of soil and sediment samples in Firtına Valley (Rize, Turkey). Applied Radiation and Isotopes, 65(11), 1281-1289.

Larsson, C.-M. (2008). An overview of the ERICA Integrated Approach to the assessment and management of environmental risks from ionising contaminants. Journal of Environmental Radioactivity, 99(9), 1364-1370.

Little, M. (2003). Risks associated with ionizing radiation Environmental pollution and health. British Medical Bulletin, 68(1), 259-275.

Livingston, H. D., \& Povinec, P. P. (2000). Anthropogenic marine radioactivity. Ocean \& Coastal Management, 43(8), 689-712.

Mabit, L, Benmansour M. Abril, J. Walling D, Meusburger, K, Jurian, A R, et a (2014). Fallout ${ }^{210} \mathrm{~Pb}$ as a soil and sediment tracer in catchment sediment budget investigations: A review. Earth-Science Reviews, 138, 335-351.

Mahu, E., Nyarko, E., Hulme, S., Swarzenski, P., Asiedu, D. K., \& Coale, K. H. (2016) Geochronology and historical deposition of trace metals in three tropical estuaries in the Gulf of Guinea. Estuarine, Coastal and Shelf Science, 177, 31-40.

Mohamed, C. A. R., Mahmood, Z. U. W., Ahmad, Z., \& Ishak, A. K. (2010). Enrichment of natural radium isotopes in the southern South China Sea surface sediments. Coastal Marine Science, 34(1), 165-171.

Nyarko, E., Botwe, B., Ansong, J., Delfanti, R., Barsanti, M., Schirone, A., et al. (2011) Determination of ${ }^{210} \mathrm{~Pb},{ }^{226} \mathrm{Ra}$ and ${ }^{137} \mathrm{Cs}$ in beach sands along the coastline of Ghana. African Journal of Environmental Pollution and Health, 9, 17-23.

Nyarko, E., Fletcher, A., Addo, S., Foli, B. A. K., \& Mahu, E. (2014). Geochemica assessment of heavy metals in surface sediments: A case study of the Tema Port, Ghana. Journal of Shipping and Ocean Engineering, 4(3-4).

Papaefthymiou, H., Papatheodorou, G., Moustakli, A., Christodoulou, D., \& Geraga, M. (2007). Natural radionuclides and ${ }^{137} \mathrm{Cs}$ distributions and their 
relationship with sedimentological processes in Patras Harbour, Greece. Journal of Environmental Radioactivity, 94(2), 55-74.

Pfitzner, J., Brunskill, G., \& Zagorskis, I. (2004). ${ }^{137} \mathrm{Cs}$ and excess ${ }^{210} \mathrm{~Pb}$ deposition patterns in estuarine and marine sediment in the central region of the Great Barrier Reef Lagoon, north-eastern Australia. Journal of Environmenta Rradioactivity, 76(1), 81-102.

Qureshi, A. A., Tariq, S., Din, K. U., Manzoor, S., Calligaris, C., \& Waheed, A. (2014) Evaluation of excessive lifetime cancer risk due to natural radioactivity in the rivers sediments of Northern Pakistan. Journal of Radiation Research and Applied Sciences, 7(4), 438-447.

Ravanat, J., Breton, J., Douki, T., Gasparutto, D., Grand, A., Rachidi, W., et al. (2014). Radiation-mediated formation of complex damage to DNA: A chemical aspect overview. The British Journal of Radiology, 87(1035), 20130715.

Sam, A., ElGanawi, A., Ahamed, M., \& ElKhangi, F. (1998). Distribution of some natural and anthropogenic radionuclides in Sudanese harbour sediments. Journal of Radioanalytical and Nuclear Chemistry, 237(1-2), 103-107.

Schmid, E., \& Schrader, T. (2007). Different biological effectiveness of ionising and non-ionising radiations in mammalian cells. Advances in Radio Science, 5(1), $1-4$.

Serigstad, B., Olsen, M., Mørk, T., Kristiansen, J., Wolinski, G., Gowing, S., et al. (2010). Marine environmental survey of bottom sediments in Cabinda and Soyo province, Angola. Cruise report No 4/2009.

Sirelkhatim, D., Sam, A., \& Hassona, R. (2008). Distribution of ${ }^{226} \mathrm{Ra}-{ }^{210} \mathrm{~Pb}-{ }^{210} \mathrm{Po}$ in marine biota and surface sediments of the Red Sea, Sudan. Journal of Environmental Radioactivity, 99(12), 1825-1828.

Sugandhi, S., Joshi, V. M., \& Ravi, P. (2014). Studies on natural and anthropogenic radionuclides in sediment and biota of Mumbai Harbour Bay. Journal of Radioanalytical and Nuclear Chemistry, 300(1), 67-70.

SureshGandhi, M., Ravisankar, R., Rajalakshmi, A., Sivakumar, S., Chandrasekaran, A. \& Anand, D. P. (2014). Measurements of natural gamma radiation in beach sediments of north east coast of Tamilnadu, India by gamma ray spectrometry with multivariate statistical approach. Journal of Radiation Research and Applied Sciences, 7(1), 7-17.

Ulanovsky, A., Pröhl, G., \& Gómez-Ros, J. (2008). Methods for calculating dose conversion coefficients for terrestrial and aquatic biota. Journal of Environmental Radioactivity, 99(9), 1440-1448.

UNSCEAR. (2000). Sources and effects of ionizing radiation: Sources (Vol. 1). New York: United Nations Publications.

Xinwei, L., Lingqing, W., \& Xiaodan, J. (2006). Radiometric analysis of Chinese commercial granites. Journal of Radioanalytical and Nuclear Chemistry, 267(3) 669-673.

Benjamin 0. Botwe is an assistant lecturer in oceanography at the Department of Marine and Fisheries Sciences of the University of Ghana. He holds an MPhil degree in
Chemistry and is currently pursuing a PhD degree at the UNESCO-IHE Institute for Water Education in the Netherlands. His current research focuses on the application of radiotracers in modelling sedimentation process in the coastal marine environment.

Antonio Schirone is researcher at the ENEA (National Agency for New Technology, Energy and Environment), Marine Environment Research Centre, La Spezia, Italy. They all hold PhD degrees and are experts in environmental radioactivity and modelling of marine environmental processes.

Ivana Delbono is researcher at the ENEA (National Agency for New Technology, Energy and Environment), Marine Environment Research Centre, La Spezia, Italy. She holds a $\mathrm{PhD}$ degree and is an expert in environmental radioactivity and modelling of marine environmental processes.

Mattia Barsanti is researcher at the ENEA (National Agency for New Technology, Energy and Environment), Marine Environment Research Centre, La Spezia, Italy. He holds a PhD degree and is an expert in environmental radioactivity and modelling of marine environmental processes.

Roberta Delfanti is researcher at the ENEA (National Agency for New Technology, Energy and Environment), Marine Environment Research Centre, La Spezia, Italy. She holds a PhD degree and is an expert in environmental radioactivity and modelling of marine environmental processes.

Peter Kelderman is a retired senior lecturer in environmental chemistry at the UNESCO-IHE Institute for Water Education. He holds a PhD degree and is an expert in environmental pollution.

Elvis Nyarko is an associate professor at the Department of Marine and Fisheries Sciences of the University of Ghana. He holds a PhD degree and is an expert in environmental pollution and he is currently the Vice Chancellor of the Regional Maritime University in Accra, Ghana.

Piet N. L. Lens is a professor at the UNESCO-IHE Institute for Water Education. He holds a PhD degree and is an expert in environmental pollution and technology. He is the chair of the pollution prevention and resource recovery chair group of UNESCO-IHE Institute for Water Education. 